of information about hepcidin and its role in the development of anemia and the response to inflammation. However, in the context of the AS, such data are contradictory and therefore need further study.

Objectives: To determine the level of hepcidin in patients with ankylosing spondylitis and to assess its relationship with hematopoiesis and ferrokinetics. Methods: The hepcidin levels of 76 patients with ankylosing spondylitis (13 women and 63 men with a mean age of $43.67 \pm 0.97$ years). The diagnosis of AS was made according to the New York modified criteria of 1984. All patients were divided into three groups: without anemia $(n=47)$, with anemia $(n=29)$ and the control group, representative by age and sex $(n=26)$. According to the percentile analysis, all patients were divided into a group with an optimal $<25 \mathrm{ng} / \mathrm{ml}$, extremely high $-25-35 \mathrm{ng} / \mathrm{ml}$ and a high level of hepcidin $>35 \mathrm{ng} / \mathrm{ml}$. In addition to hepcidin, hematopoiesis and ferrokinetic parameters were measured in each patient: hemoglobin $(\mathrm{Hb})$, erythrocyte, MCV, serum iron, total serum iron-binding capacity (TIBC), serum ferritin, transferrin saturation (TS). Statistical processing of the obtained results was performed with the use of statistical software package "Microsoft Office Excel 2007".

Results: When conducting a percentile comparison in $95 \%$ of people in the control group, the level of hepcidin was in the range of $17.97-38.8 \mathrm{ng} / \mathrm{ml}\left(\mathrm{P}_{5}-\mathrm{P}_{95}\right)$, and in patients with AS in $95 \%-14.62-87.38 \mathrm{ng} / \mathrm{ml}$. At $P_{95}$, the level of hepcidin in patients with $\mathrm{AS}$ was 2.3 times higher than in $\mathrm{P}_{95}$ control group. Comparing the mean values of hepcidin, a significant difference was found between the group of patients without anemia, where it was $36.08 \pm 2.57 \mathrm{ng} / \mathrm{ml}$ and the group of patients with anemia, where the level of hepcidin was $51.77 \pm 4.62 \mathrm{ng} / \mathrm{ml}$. The lowest level of hepcidin was in patients with IDA $(35.8 \pm 7.50 \mathrm{ng} / \mathrm{ml})$, and the highest $(62.78 \pm 5.94 \mathrm{ng} / \mathrm{ml})$ - among patients with ACD. The group of patients with ACD and iron deficiency, according to the levels of hepcidin $(48.53 \pm 9.50 \mathrm{ng} / \mathrm{ml})$ took an intermediate place.

In terms of hematopoiesis and ferrokinetics, the level of hemoglobin and erythrocytes did not differ significantly between the groups of optimal, extremely high and high levels of hepcidin. According to the levels of serum iron, TS and ferritin in the group of patients with anemia, a significant association with hepcidin was established (with increasing levels of hepcidin, the values of serum iron, TS and ferritin also increased). In contrast,sTfR levels were the highest in the group with optimal hepcidin levels $(6.02 \pm 0.71 \mathrm{mg} / \mathrm{l})$ and decreased to $4.88 \pm 0.64 \mathrm{mg} / \mathrm{l}$ in the group with high hepcidin levels. Such changes in hematopoiesis and ferrokinetics were explained by the accumulation of mostly people with symptoms of ACD in the group with high levels of hepcidin, and the group with optimal levels of hepcidin consisted mainly of patients with IDA.

Conclusion: Patients with AS have elevated serum hepcidin levels, it is higher in individuals with anemic syndrome than in patients without anemia and is associated with serum iron, TS and ferritin levels.

Disclosure of Interests: None declared.

DOI: 10.1136/annrheumdis-2021-eular.382

\section{AB0488 $\quad$ SPONDYLOARTHRITIS DISEASE BURDEN AS PERCEIVED BY PATIENTS: BASELINE PATIENT- REPORTED OUTCOME DATA FROM THE ITALIAN PROSPECTIVE SIRENA STUDY}

R. Foti ${ }^{1}$, G. Cardinale ${ }^{2}$, L. Costa ${ }^{3}$, F. Franceschini ${ }^{4}$, F. Ciccia $^{5}$, A. Marchesoni ${ }^{6}$, G. Guggino ${ }^{7}$, M. Rossini ${ }^{8}$, E. Lubrano DI Scorpaniello ${ }^{9}$, B. Frediani ${ }^{10}$, M. S. Chimenti ${ }^{11}$, G. Bianchi ${ }^{12}$, G. Galfo ${ }^{13}$, S. Marelli ${ }^{14}$, E. Favalli ${ }^{15}$ on behalf of SIRENA Study Group. ${ }^{1}$ Azienda Ospedaliero Universitaria Policlinico Vittorio Emanuele, U.O. Reumatologia, Catania, Italy; ${ }^{2}$ Distretto nr. 1 ULSS6 Euganea, U.O.S. Reumatologia, Padova, Italy; ${ }^{3}$ Università degli Studi di Napoli Federico II, U.O.C. Reumatologia, Dipartimento di Medicina Clinica e Chirurgia, Naples, Italy; ${ }^{4}$ ASST Spedali Civili, Università di Brescia, U.O.C. Reumatologia and Immunologia Clinica, Dept of Clinical and Experimental Sciences, Brescia, Italy; ${ }^{5}$ Università della Campania L Vanvitelli, U.O.C. Reumatologia, Dipartimento di Medicina di Precisione, Naples, Italy; ${ }^{6}$ ASST Centro Specialistico Ortopedico Traumatologico Gaetano Pini - CTO, S.C. Day Hospital di Reumatologia, Milan, Italy; ${ }^{7} \mathrm{AOU}$ Policlinico Paolo Giaccone e Università degli Studi di Palermo, U.O. Reumatologia, Palermo, Italy; ${ }^{8}$ Azienda Ospedaliera Universitaria Integrata, U.O.C. Reumatologia, Verona, Italy; ${ }^{9}$ Università degli Studi del Molise, U.O.S. V.D. Reumatologia, Dipartimento di Medicina e Scienze della Salute, Campobasso, Italy; ${ }^{10}$ Azienda Ospedaliera Universitaria Senese, U.O.C. Reumatologia, Siena, Italy; ${ }^{11}$ Università di Roma Tor Vergata, Reumatologia, Allergologia e Immunologia Clinica, Dipartimento di Medicina dei Sistemi, Rome, Italy; ${ }^{12}$ ASL3 Genova, S.C. Reumatologia, Genova, Italy; ${ }^{13}$ Azienda Provinciale Sanitaria di Ragusa, U.O. Reumatologia e Medicina Generale, Lungodegenza Ospedale Busacca, Scicli (RG), Italy; ${ }^{14}$ Janssen, Medical Affairs Department, Immunology, Cologno Monzese (MI), Italy; ${ }^{15}$ ASST Centro Specialistico Ortopedico Traumatologico Gaetano Pini - CTO, S.C. Reumatologia, Milan, Italy

Background: Previous studies have compared Patient-Reported Outcomes (PROs) in Spondyloarthritis (SpA); a recent one has found similarity in Psoriatic Arthritis (PsA) and axial patients ${ }^{1}$.
Objectives: To describe PROs at SpA diagnosis (new or confirmed), by type of SpA and by gender.

Methods: SIRENA is an Italian, prospective Registry of SpA patients diagnosed according to ASAS criteria and naïve to any DMARDs. At inclusion, patients were classified as predominant axial (AxSpA) or mainly peripheral (pSpA). PROs showed in the Table 1 were collected and analysed descriptively.

Table 1. PhGA and PROs at diagnosis*

\begin{tabular}{|c|c|c|c|c|c|c|}
\hline & $\mathrm{AxSpA}^{*}$ & & & pSpA & & \\
\hline & $\begin{array}{l}\text { All } \\
(n=123)\end{array}$ & $\begin{array}{l}\text { Women } \\
(n=64)\end{array}$ & $\begin{array}{l}\text { Men } \\
(n=58)\end{array}$ & $\begin{array}{l}\text { All } \\
(n=227)\end{array}$ & $\begin{array}{l}\text { Women } \\
(n=109)\end{array}$ & $\begin{array}{l}\text { Men } \\
(n=118)\end{array}$ \\
\hline PhGA, $n$ & 115 & 60 & 54 & 222 & 105 & 117 \\
\hline mean (SD) & $50.2(28.6)$ & $54.8(26.7)$ & $45.0(30.1)$ & $45.4(25.9)$ & $49.9(25.6)$ & $\begin{array}{l}41.3 \\
(25.6)\end{array}$ \\
\hline median $(\min , \max )$ & $52.0(0-100)$ & $62.0(0-100)$ & $\begin{array}{l}43.5 \\
(0-100)\end{array}$ & $48.5(0-100)$ & $\begin{array}{l}50.0 \\
(1.0-100)\end{array}$ & $\begin{array}{l}40.0 \\
(0-95.0)\end{array}$ \\
\hline $\begin{array}{l}\text { PtGA, } \mathbf{n} \\
\text { mean (SD) }\end{array}$ & $\begin{array}{l}112 \\
56.4(27.8)\end{array}$ & $\begin{array}{l}59 \\
61.5(25.8)\end{array}$ & $\begin{array}{l}52 \\
50.3(29.2)\end{array}$ & $\begin{array}{l}209 \\
50.3(26.2)\end{array}$ & $\begin{array}{l}102 \\
56.4(23.1)\end{array}$ & $\begin{array}{l}107 \\
44.5\end{array}$ \\
\hline & & & & & & $(27.7)$ \\
\hline median (min, max) & $63.0(0-100)$ & $\begin{array}{l}70.0 \\
(2.0-100)\end{array}$ & $\begin{array}{l}50.0 \\
(0-100)\end{array}$ & $50.0(0-100)$ & $\begin{array}{l}58.5 \\
(7.0-100)\end{array}$ & $\begin{array}{l}47.0 \\
(0-100)\end{array}$ \\
\hline $\begin{array}{l}\text { Pain VAS score, } \mathbf{n} \\
\text { mean (SD) }\end{array}$ & $\begin{array}{l}113 \\
56.7(28.3)\end{array}$ & $\begin{array}{l}60 \\
61.1(26.6)\end{array}$ & $\begin{array}{l}52 \\
50.6(29.1)\end{array}$ & $\begin{array}{l}207 \\
51.9(26.8)\end{array}$ & $\begin{array}{l}101 \\
57.4(25.3)\end{array}$ & $\begin{array}{l}106 \\
46.8\end{array}$ \\
\hline median (min, $\max )$ & $60.0(0-100)$ & $\begin{array}{l}69.5 \\
(2.0-100)\end{array}$ & $\begin{array}{l}50.0 \\
(0-100) \\
52\end{array}$ & $53.0(0-100)$ & $61.0(0-100)$ & $\begin{array}{l}(27.3) \\
48.5 \\
(0-100) \\
108\end{array}$ \\
\hline $\begin{array}{l}\text { leep VAS S } \\
\text { mean (SD) }\end{array}$ & $55.3(29.3)$ & $57.4(29.5)$ & $52.3(29.2)$ & $44.0(30.1)$ & $50.4(29.8)$ & $\begin{array}{l}108 \\
37.9 \\
(29.2)\end{array}$ \\
\hline median $(\min , \max )$ & $59.0(0-100)$ & $61.5(0-100)$ & $\begin{array}{l}53.0 \\
(0-100)\end{array}$ & $44.0(0-100)$ & $53.0(0-100)$ & $\begin{array}{l}34.0 \\
(0-100)\end{array}$ \\
\hline BASFI, n & 110 & 58 & 51 & 133 & 65 & 68 \\
\hline mean (SD) & $4.6(2.8)$ & $5.2(2.6)$ & $3.9(2.8)$ & $3.5(2.6)$ & $4.0(2.6)$ & $\begin{array}{l}3.1 \\
(2.4)\end{array}$ \\
\hline median (min, max) & $5.1(0-9.7)$ & $5.8(0-9.4)$ & $3.6(0-9.6)$ & $2.9(0-10.0)$ & $3.9(0-10.0)$ & $\begin{array}{l}2.45 \\
(0-8.9)\end{array}$ \\
\hline ASDAI, n & 112 & 59 & 52 & 139 & 70 & 69 \\
\hline mean (SD) & 5.2( & 5.8 & $4.5(2.3)$ & $5.2(2.3)$ & $5.8(2.1)$ & $\begin{array}{l}4.6 \\
(2.3)\end{array}$ \\
\hline median (min, max) & $5.5(0-9.3)$ & $6.2(0-9.3)$ & $\begin{array}{l}4.5 \\
(0.3-9.2)\end{array}$ & $\begin{array}{l}5.5 \\
(0.2-10.0)\end{array}$ & $\begin{array}{l}6.1 \\
(1.0-10.0)\end{array}$ & $\begin{array}{l}4.8 \\
(0.2-9.2)\end{array}$ \\
\hline HAQ-DI score, $n$ & 109 & 58 & 50 & 203 & 99 & 104 \\
\hline mean (SD) & $0.9(0.7)$ & $1.1(0.7)$ & $0.6(0.6)$ & $0.7(0.7)$ & $0.9(0.7)$ & $\begin{array}{l}0.6 \\
(0.6)\end{array}$ \\
\hline median (min, $\max$ ) & $0.8(0.0-2.5)$ & $1.1(0-2.5)$ & $0.5(0-2.3)$ & $0.6(0.0-2.8)$ & $0.8(0-2.8)$ & $\begin{array}{l}0.4 \\
(0-2.6)\end{array}$ \\
\hline \multicolumn{7}{|l|}{ WPAI } \\
\hline $\begin{array}{c}\% \text { work time } \\
\text { missed, } n\end{array}$ & 49 & 19 & 30 & 107 & 45 & 62 \\
\hline mean (SD) & $7.3(21.4)$ & $4.2(9.5)$ & $9.2(26.3)$ & $8.8(24.7)$ & $8.6(25.6)$ & $\begin{array}{l}8.9 \\
(24.3)\end{array}$ \\
\hline median (min, max) & $0(0-100)$ & $0(0-35.1)$ & $0(0-100)$ & $0(0-100)$ & $0(0-100)$ & $\begin{array}{l}0 \\
(0-100)\end{array}$ \\
\hline $\begin{array}{l}\text { \% impairment at } \\
\text { work, } n\end{array}$ & 67 & 33 & 34 & 134 & 61 & 73 \\
\hline mean (SD) & $48.2(31.9)$ & $58.5(26.6)$ & $38.2(33.7)$ & 39.7 (31.4) & $45.4(30.9)$ & $\begin{array}{l}34.9 \\
(31.2)\end{array}$ \\
\hline median (min, max) & $50.0(0-100)$ & $60.0(0-100)$ & $\begin{array}{l}25.0 \\
(0-100)\end{array}$ & $40.0(0-100)$ & $50.0(0-100)$ & $\begin{array}{l}30.0 \\
(0-100)\end{array}$ \\
\hline $\begin{array}{l}\text { \% overall work } \\
\quad \text { impairment, } n\end{array}$ & 48 & 19 & 29 & 106 & 45 & 61 \\
\hline mean (SD) & $44.1(33.0)$ & $52.4(27.9)$ & 38.7 (35.3) & $40.1(33.0)$ & $45.1(33.1)$ & $\begin{array}{l}36.4 \\
(32.7)\end{array}$ \\
\hline median (min, max) & $45.0(0-100)$ & $60.0(0-100)$ & $\begin{array}{l}20.0 \\
(0-100)\end{array}$ & $40.0(0-100)$ & $50.0(0-100)$ & $\begin{array}{l}30.0 \\
(0-100)\end{array}$ \\
\hline $\begin{array}{l}\% \text { activity impair- } \\
\text { ment, } n\end{array}$ & 100 & 53 & 46 & 183 & 93 & 90 \\
\hline mean (SD) & $56.7(28.6)$ & $63.4(23.9)$ & $48.0(31.0)$ & $48.5(30.3)$ & $55.3(28.7)$ & $\begin{array}{l}41.4 \\
(30.4)\end{array}$ \\
\hline median (min, max) & $60.0(0-100)$ & $70.0(0-100)$ & $\begin{array}{l}50.0 \\
(0-100)\end{array}$ & $50.0(0-100)$ & $60.0(0-100)$ & $\begin{array}{l}40.0 \\
(0-100)\end{array}$ \\
\hline
\end{tabular}

* The sum does not add up to the total because of some missing values.

Results: From 23 sites, $123 \mathrm{AxSpA}$ and $227 \mathrm{pSpA}$ patients were analysed. Diagnosis was new in $58 \%$ of AxSpA and $77 \%$ of pSpA. $85.5 \%$ of the pSpA had PsA, while in AxSpA the most frequent type was Ankylosing Spondylitis (48.8\%). Time from symptom onset to diagnosis was higher in AxSpA than in pSpA (median 36 vs 24 months, respectively). At inclusion, composite disease activity measures showed high disease activity for AxSpA (mean ASDASCRP 3.1) and moderate disease activity for pSpA (mean DAS28 3.6; mean DAPSA 22.5). AxSpA patients had numerically worse values than $p S p A$ in all the PROs collected, except for BASDAI score that was similar (mean 5.2). For both AxSpA and pSpA, all PROs were worse in women than men, except 
for the \% of work time missed. PtGA scores were higher than PhGA, in each group and gender.

Conclusion: At diagnosis, SpA patients perceive a slightly higher disease burden than assessed by Physicians. For PROs other than BASDAI, AxSpA reported a worse impact than $\mathrm{pSpA}$. Overall, women showed a higher disease impact than men.

References: [1]Michelsen B. et al. PLoS ONE 2015; 10(4): e0123582.

Disclosure of Interests: Rosario Foti Speakers bureau: Speaker bureau honoraria from Eli Lilly, Sanofi, MSD, Janssen, AbbVie, Bristol-Myers Squibb, Celgene, Roche, Consultant of: Consultancy fees from Eli Lilly, Sanofi, MSD, Janssen, AbbVie, BMS, Celgene, Roche, Gabriella Cardinale: None declared., Luisa Costa: None declared., Franco Franceschini: None declared., Francesco Ciccia Speakers bureau: Speaker bureau honoraria from AbbVie, Abiogen, Bristol-Myers Squibb, Celgene, Janssen, Eli Lilly, Pfizer, Novartis, Roche, Consultant of: Consultancy fees from Novartis, Pfizer, Janssen, Eli Lilly, Roche, Celgene, Grant/research support from: Grant/research support from Pfizer, Novartis, Celgene, Janssen, Roche, Antonio Marchesoni: None declared., Giuliana Guggino Speakers bureau: Speaker bureau honoraria from Celgene, Sandoz, Pfizer, Grant/research support from: Grant/research support from Pfizer, Celgene, Maurizio Rossini: None declared., Ennio Lubrano Di Scorpaniello: None declared., Bruno Frediani: None declared., Maria Sole Chimenti: None declared., Gerolamo Bianchi: None declared., Giuseppe Galfo: None declared., Silvia Marelli Employee of: Employee of Janssen-Cilag SpA Italy, Ennio Favalli Speakers bureau: Consulting fees and/or speaking engagements from AbbVie, Bristol-Myers Squibb, Lilly, Merck Sharp \& Dohme, Pfizer, Galapagos, Sanofi-Genzyme, and UCB.

DOI: 10.1136/annrheumdis-2021-eular.624

\section{AB0489 \\ CORRELATION BETWEEN DISEASE ACTIVITY AND SERUM TNF-ALPHA LEVELS IN PATIENTS WITH ANKYLOSING SPONDYLITIS}

K. Kraev ${ }^{1,2}$, M. Geneva-Popova ${ }^{1,3}$, S. Popova ${ }^{1,3} .{ }^{1}$ Medical University Plovdiv, Propedeutics of Internal Diseases, Plovdiv, Bulgaria; ${ }^{2}$ Multiprofile Hospital for Active Treatment "Kaspela", Rheumatology, Plovdiv, Bulgaria; ${ }^{3}$ Multiprofile Hospital for Active Treatment "St.George", Rheumatology, Plovdiv, Bulgaria

Background: Ankylosing spondylitis (AS) is an immune-mediated rheumatic disease, it belongs to the spectrum of the axial spondyloarthritis. Several elements are important for the pathogenesis of AS - they include interactions in the context of a specific genetic origin between the intestinal microbiome, innate immunity, lymphoid cells and anatomical structures, which are the entheses of the axial skeleton and peripheral joints. The main mediators of the inflammatory process are TNF - $\alpha$, IL-17 and IL-17A.

Objectives: To study the level of TNF-alpha in the serum of patients with ankylosing spondylitis and to assess its relationship with the indices of disease activity before starting therapy with TNF-alpha blockers and in the dynamics after initiation of treatment.

Methods: The present study included 50 patients with ankylosing spondylitis and 31 healthy controls similar in age, sex, and BMI. Clinical and non-clinical methods of examination and evaluation were used for proper assessment and follow-up of patients. The disease activity indices that were used were BASDAI and ASDAS. Statistical analysis was performed with the IBM SPSS program, v.24., To prove the relationship between the level of TNF-alpha in the serum of patients and disease activity, a correlation analysis of Spearman Rho was used. Results: The level of TNF- $\alpha$ in patients with AS was highest before treatment initiation with biologics, $89.77 \pm 36.89 \mathrm{pg} / \mathrm{ml}$, and was significantly higher than that of healthy controls. At the next visit, the TNF- $\alpha$ level decreased to $27.59 \pm 23.88$ $\mathrm{pg} / \mathrm{ml}$, the difference being significant from baseline. 24 months after initiation of treatment with biological therapy average level of TNF- $\alpha$ in patients with AS did not differ reliably from its levels in 6 and 12 month after initiation of treatment, respectively, $22.36 \pm 22.38 \mathrm{pg} / \mathrm{ml}, 19,29 \pm 21.07 \mathrm{pg} / \mathrm{ml}$. The level of this cytokine significantly correlates with the activity of the disease, measured by the activity indices BASDAI, ASDAS.

Conclusion: The level of the pro-inflammatory cytokine TNF-alpha is significantly higher in patients with ankylosing spondylitis and significantly correlates with the disease activity in them, measured by the respective indices (BASDAI, ASDAS).

\section{REFERENCES:}

[1] Arends S., N. Lebbink, A. Spoorenberg et al., "The formation of autoantibodies and antibodies to TNF- $\alpha$ blocking agents in relation to clinical response in patients with ankylosing spondylitis", Clin Exp Rheumatol, 2010, 28: 661- 668.

[2] Bal A., E. Unlu, G. Bahar et al., "Comparison of serum IL-1 beta, sIL-2R, IL-6, and TNF-alpha levels with disease activity parameters in ankylosing spondylitis." Clin Rheumatol, 2007, 26: 211-215.

Disclosure of Interests: None declared.

DOI: 10.1136/annrheumdis-2021-eular.931

\section{AB0490 IMPACT OF SPONDYLOARTHRITIS ON WORK PRODUCTIVITY: A REAL LIFE STUDY}

M. Ben Majdouba ${ }^{1}$, S. Boussaid ${ }^{1}$, S. Rekik ${ }^{1}$, S. Jemmali ${ }^{1}$, H. Ajlani ${ }^{1}$, H. Sahli ${ }^{1}$ M. Elleuch ${ }^{1} .{ }^{1}$ La Rabta hospital, Rheumatology, Tunis, Tunisia

Background: Work productivity of patients with spondyloarthritis is frequently affected by their disease.

Objectives: We aim to identify disease-related factors associated with poor work productivity in patients with spondyloarthritis.

Methods: A cross-sectional study was performed in patients with spondyloarthritis. Data on disease characteristics were collected as well as specific indices: Visual analogue scale (VAS) for fatigue and pain, Bath Ankylosing Spondylitis Disease Activity Index (BASDAI), Ankylosing Spondylitis Disease Activity Score with CRP (ASDAS-CRP), Bath Ankylosing Spondylitis Functionnel Index (BASFI) and Bath Ankylosing Spondylitis Metrology Index (BASMI). EuroQol-5D (EQ5D) was used to assess health-related quality of life. Work productivity was assessed by the Work Productivity and Activity Impairment scale (WPAI:SpA). Factors associated with presenteeism, absenteeism and work productivity loss were evaluated. Results: One hundred patients were enrolled ( 73 men and 27 women); mean age was $43.68 \pm 10.3$ years. Fifty nine percent of patients were employed, $26 \%$ were off work and $15 \%$ were retired of which $8 \%$ were in early retirement. Sixty seven percent of patients had ankylosing spondylitis, $17 \%$ had rheumatism associated with inflammatory bowel disease and $16 \%$ had psoriatic rheumatism. The average disease duration was $12.24 \pm 8.73$ years. Mean age at onset was 33.2 \pm 10 years [18-59]. The average diagnostic delay was $2.41 \pm 3$ years; it was more than five years in $17 \%$ of cases. Sacroiliac pain has been noted in 69 patients lumbar or cervical stiffness in 78 patients and peripheral joint involvement in 18 cases. Thirty one percent of patients had hip joint involvement and $49 \%$ had extra-articular manifestation. Fifty percent had inflammatory biological syndrome $63 \%$ were treated with anti-TNF $\alpha$ and $58 \%$ needed symptomatic treatment regularly. The mean fatigue and pain VAS was respectively $5.58 \pm 2.5$ and $5.56 \pm$ 2.9. The mean BASDAI was $4.4 \pm 2.4$, the average BASFI was $4.6 \pm 2.7$ and the average ASDAS-CRP was $2.77 \pm 1$. 18 . The mean BASMI was $4.4 \pm 2.8$. The mean EQ5D score was $0.485 \pm 0.378$. Among employed patients, mean absenteeism, presenteeism and work productivity loss was $21.8 \pm 33.13 \%, 42 \pm 32 \%$ and $46.5 \pm 35.31 \%$, respectively. These work outcomes were correlated to diagnostic delay $\geq 2$ years $(p<0.03)$, peripheral joint involvement $(p=0.006)$, psoriasis $(p=0.02)$, inflammatory biological syndrome $(p<0.001)$, need of symptomatic treatment $(p=0.001)$, fatigue and pain VAS $\geq 4(p<0.001), B A S D A I \geq 4(p<0.001)$, ASDAS-CRP $\geq 2.1(p<0.001)$, BASFI $\geq 4(p<0.001)$, BASMI $\geq 4(p=0.002)$ and low EQ5D score $(p<0.001)$. Work productivity loss was in addition correlated to age at onset $<25$ years $(p=0.03)$

Conclusion: Active disease, reduced physical function and poorer quality of life are associated with reduced work productivity. Early diagnosis and good disease management especially fatigue and pain can potentially improve work outcomes in patients with spondyloarthritis.

Disclosure of Interests: None declared.

DOI: 10.1136/annrheumdis-2021-eular.1079

\section{AB0491 THE IMPORTANCE OF MUSCULOSKELETAL SYMPTOM QUESTIONING IN INFLAMMATORY BOWEL DISEASES}

B. Farisoğulları ${ }^{1}$, O. Keskin ${ }^{2}$, B. Usta ${ }^{3}$, G. K. Yardımcı ${ }^{1}$, E. Parlak ${ }^{2}$, T. Kav ${ }^{2}$ U. Kalyoncu ${ }^{1}$, O. Karadag ${ }^{1} .{ }^{1}$ Hacettepe University, Faculty of Medicine, Department of Internal Medicine, Division of Rheumatology, Ankara, Turkey; ${ }^{2}$ Hacettepe University, Faculty of Medicine, Department of Internal Medicine, Division of Gastroenterology, Ankara, Turkey; ${ }^{3}$ Hacettepe University, Faculty of Medicine, Department of Internal Medicine, Ankara, Turkey

Background: Spondyloarthritis (SpA) occurs in up to $13 \%$ of patients with inflammatory bowel disease (IBD) (1). Early diagnosis and treatment of SpA in IBD patients prevents irreversible musculoskeletal diseases.

Objectives: The aim of this study is to emphasize the importance of questioning musculoskeletal symptoms in patients with IBD.

Methods: In the Hacettepe University Gastroenterology Clinic, patients with IBD were questioned for musculoskeletal symptoms between March 2019 and September 2020. For this purpose, a validated DETAIL questionnaire (2) consisting of six questions was asked (1. Have you ever had a finger or a toe and/or another joint swollen and painful for no apparent reason? 2. Occasionally, has an entire finger or toe becomes swollen, making it look like a 'sausage'? 3. Have you had pain in your heels? 4. Have you ever had back pain lasting at least 3 months that was not injury related? 5 . Do you have low back pain in the morning and/or after resting that improves with exercise? 6 . Do you wake up at night because of low back pain?). Patients with at least 1 positive out of 6 questions were consulted in the rheumatology clinic, and patients were evaluated for SpA by physical examination, laboratory, and imaging. Demographic and clinical characteristics of IBD patients with and without SpA were compared. 